\title{
JAPANESE CULTURAL TRANSITION: \\ MEIJI ARCHITECTURE AND THE EFFECT OF CROSS-CULTURAL EXCHANGE WITH THE WEST \\ By Christine Manzano Visita
}

"Here, now, comes the greatest revolutionary epoch! These are the two great events, the restoration of the Imperial power from the lands of the last Shogun after the end of several wars, followed by the opening of our communication and the forming of our treaties with the western world!"

- Funakoshi Kinya, Imperial College of

Engineering graduation thesis, $1883^{1}$

The class of 1879 and 1883 at the Imperial College of Engineering in Tokyo set out to create comprehensive theses about the future of architecture in Japan, looking to new materials, foreign forms, and revolutionary engineering to describe the development of the architectural landscape of Japan as they tried to adapt to Western influence. One of the students, Sone Tatsuzo, made several points within his essay marking the essence of what the

${ }^{1}$ Funakoshi Kinya, "The Adoption of European Architecture in Japan" (Graduation thesis, Imperial College of Engineering, 1883), 6. 
future of Japanese architecture entailed in the Meiji era: the combination of European styles and materials with Japanese forms to create an architectural atmosphere that was most conducive to the Japanese in the modernizing era. All of the students, in some capacity, addressed the combination of Western and European ideas and technology that were making their way into the cultural tapestry of Japan. For the Japanese, this struggle between modernity and tradition was a way to find a foothold in the ever changing environment of the world.

Botond Bognar, in his work Contemporary Japanese Architecture, breaks down the conflict observed by both Japanese and foreigners alike between the modern and the traditional into a situation characterized by not choosing one or the other but by choosing to inter-mix each side. Foreign influence on Japanese architecture did not start with the use of Western styles, but had been present in its history for centuries through other countries such as China and Korea. In those situations and during the age of Western influence, Japan's decision to learn the different techniques and building styles had always been about creating a "both-and" situation rather than an "either-or." Instead of trying to make a clear decision about using one specific style of architecture over another in building structures, the Japanese would apply aspects of foreign forms to the already developed forms of Japanese designs, utilizing both modern and traditional types of architectural elements.

Looking towards the influence that the West had on Japanese architecture, one way to analyze the infusion of modern styles into the more traditional methods includes understanding the importance of national identity to the Japanese. Arata Isozaki uses the idea of "Japan-ness" to describe the effect of Western influence on what was considered "pure" Japanese style of architecture. ${ }^{3}$ In his book, Japan-ness In Architecture, Isozaki describes Japan-ness as a reflection of the idea of the unique prevailing tastes and ideas of what Japanese style was. This perception of Japanese style was formed through observations made by Western architects such as Frank

${ }^{2}$ Botond Bognar, Contemporary Japanese Architecture (New York: Van Nostrand Reinhold Company, Inc, 1985), 13.

${ }^{3}$ Arata Isozaki, Japan-ness in Architecture, ed. David B. Stewart, trans. Sabu Kohso (Massachusetts: The MIT Press, 2006), 3. 
Lloyd Wright, an American architect, and Bruno Taut from Germany. Japan's own cultural identity, its Japan-ness, was, therefore, a product of Westerners, people who were not actually part of Japanese society but just observers. Though this idea of Japan-ness started with foreigners, the idea of Japan's own unique style and essence-their own national identity-was held within the Japanese people years before the Western characterization was created.

The architecture of Japan was a symbol of their innovation, their culture, and history, so with the influence of Western ideas affecting their architecture, the Japanese who had significant interaction with Westerners and their technology had to deal with adjusting what represented them in order to keep up with the expanding Western trend. Changing from traditional wood and brick design to the uses of steel and glass and other modern materials marked a metamorphosis in the look and meaning of Japanese architecture as the Japanese people moved into a more modern society and adjusted to increasing international relations. Becoming a larger part of the "world order," as Seizaburo Sato describes in his essay in Modern Japan: an Interpretive Anthology, evoked a certain reaction to the cultural changes brought on through architecture. ${ }^{4}$

The education of Japanese scholars in Japan and in other countries, particularly in Europe, proved to be a pathway within which Western ideas traveled through to the consciousness of the Japanese. Within his article "Teaching Architectural History in Japan: Building a Context for Contemporary Practice" in The Journal of the Society of Architectural Historians, Jonathan Reynolds focuses on the pedagogy of architectural history in Japan. He calls attention to the infusion of Western and modern technology, materials, and styles into the awareness of Japanese architectural students during the Meiji period through curriculum at institutions such as the Imperial University. ${ }^{5}$

The Meiji Restoration in Japan, which began in 1868, brought an influx of Western ideas and injected modern technology into a flourishing nation

“ Seizaburo Sato, "Japan's World Order," in Modern Japan: an Interpretive Anthology, ed. Irwin Scheiner (Princeton, NJ: Princeton University Press, 1971), 9-17.

${ }^{5}$ Jonathan Reynolds, "Teaching Architectural History in Japan: Building a Context for Contemporary Practice," The Journal of the Society of Architectural Historians, 61, no. 4 (Dec, 2002): 531 
that, at the time, was opening its boundaries to the West in an attempt to acquire knowledge that would help them attain a more powerful position among other Western countries. Architecture marked one of the aspects of Japanese culture that felt the effects Japan's struggle to find its place within the changing landscape of the world politically, socially, economically, and culturally. This paper will address the idea that the education of the Japanese in Western ways and the added interest in finding a way to become a world power in the context of politics and economics not only affected the architectural landscape of Japan but also affected the notions of national identity, Japan's status in the international realm, and other cultural and social constructs found within Japan. The ideals of tradition and modernization came together in the context of architecture and reflected these changes that Japan faced as it evolved into a more industrialized, modern nation during the Meiji Period and into the twentieth century.

\section{Motivations in Changing Japan's Landscape}

"A nation unique and precious as this was, could not fall behind others in power..."

- Thomas C. Smith, "Old Values and New Techniques in the Modernization of Japan", $1955^{6}$

The rapid succession with which advancing technology was introduced to Japan as the world modernized led the Japanese to realize that they had to be able to keep up with the changes in order to become a greater power in the international realm. The Western nations were categorized as part of the world that had the most success in terms of the advancement of technology, the education of people in politics, economics, and other contributing factors to a modern and industrial nation. The Western nations proved that they had a strong presence as influential countries through their endeavors abroad, including colonization toward imperialistic success. As an Eastern nation, it was important for Japan to prove that they could

\footnotetext{
"Thomas C. Smith, "Old Values and New Techniques in the Modernization of Japan," in Modern Japan: An Interpretive Anthology, ed. Irwin Scheiner (New York: Macmillan Publishing Co., Inc., 1974), 95.
} 
contribute as much or even more to the international sphere as the Western world, as well as impose their ideas of how the world should work. At the time of the Meiji Restoration, Japan was looking towards extending greater influence over their Asian counterparts in their area such as China and Korea. The Japanese believed that they were the most capable of the Eastern nations to show other Asian nations how they should conduct themselves in order to avoid exploitation of their nation and resources by Western rulers looking to gain power.

"In quick advance of civilization no nation could be compared with the Japanese who are in a burning emotion to rank especially with the most civilized nations of the world," Sone Tatsuzo wrote as one of his observations of Japan's condition was at that point in the Meiji era. ${ }^{7}$ Breaking down this idea of advancing into a more civilized nation, there were two differing concepts of where the Japanese saw themselves in comparison to the rest of the world. First they saw themselves as a strong and unique country to which no other nation could be compared, giving them an air of superiority. But even with the confidence that the Japanese had concerning their ability to develop and advance into a great nation, they were aware that there were still other nations with whom they had to compete.

Japan's Meiji elite were confident of their formula for rising up in the ranks of the international scene with military power and wealth. ${ }^{8}$ Japan's goal in adapting to Western ideas, including technology, was to try and rise through the ranks by keeping up with the Western powers and establish themselves as an Eastern nation of equal status. In the eyes of the Western powers, Japan stood as one of the more modern and more "civilized" Asian countries. ${ }^{9}$ They were poised with potential to show their strengths economically, militarily, and culturally; the Japanese did not fail to demonstrate their capabilities as they adjusted to new technology rapidly and made strides to expand their control through their military might and economic interests in the neighboring countries of China, Korea, the Philippines, and others.

The Japanese were adept at taking on aspects of Western society and

7 Sone Tatsuzo, "The Future Domestic Architecture" (Graduation thesis, Imperial College of Engineering, 1879), 18.

${ }^{8}$ Sato, 15.

${ }^{9}$ Sato, 15 . 
technology within their own country's structure, but they also wanted to ensure that they were not completely under the influence of the Western nations. They continued to move towards their goal of spreading their control and influence throughout the Asian countries in order to create an "empire" that could rival the Western nations. By going into places like China, the Japanese could diffuse their thoughts on how an Asian nation should organize and build up their country. The adaptation of more modern technology and ideas were seen as a way to improve, not only the physical landscape of Japan, but also the economical and political scene. These improvements were made to ensure that Japan would become a prominent power in the East as well as keep themselves from being taken over by Western nations that had influence in the Asian countries through colonization, politics, and the economics of trading.

\section{Western Education, Technology, and Superiority?}

"The science of Architecture has been laid in our college as
one of the main professional branches of study and the true
principles of European Architecture is being here taught with
the view of learning their true principles in our country..."
- Funakoshi Kinya, Imperial College of
Engineering graduation thesis, $1883^{10}$

At the same time as Japan was opening itself to the West, the educational system underwent major reconstruction. The national spirit of a country was paramount in the formation of a strong exterior front shown to the international world. The educational system looked towards developing that spirit, emphasizing that the most important point of education was "pointing the direction toward which the whole nation should march."11

The Minister of Education from 1886 to 1889, Mori Arinori, created new educational ordinances and reforms that encouraged education sys-

\footnotetext{
${ }^{10}$ Funakoshi, 9.

${ }^{11}$ Joseph Pittau, "Inoue Kowashi (1843-1895) and the Meiji educational system," in Modan Japan: An Interpretive Anthology, ed. Irwin Schiener (New York: Macmillan Publishing Co., Inc., 1974), 178.
} 
tems and institutions to "teach the arts and sciences essential to the state."12 The educational content of the schools and universities being formed were to have a basis in concepts that would contribute to the building of a powerful nation. Such concepts included Confucianism that would emphasize tradition, but not reject modernization of the state. ${ }^{13}$ In order to bring better education to the Japanese, it was important for ministers of Japan to focus the attention of the country to the type of programs that would best benefit their future, which included the impressionable youth of the nation.

One such minister, Inoue Kowashi, looked at the encroaching industrialization and modernization and tried to adjust the educational system to accommodate changing times. In order to better prepare the citizens of Japan for the new age of technology, the educational system had to provide students with the skills to advance them into the burgeoning industrial society. There was more vocational training and technical education in industrial skills such as architectural design, mechanical engineering, and other forms of engineering that would help establish the Japanese at the forefront of research and development of new ideas. The reformation of the educational programs improved the possibility of Japan gaining better status by keeping up the pace of where the world as a whole was going in terms of technical, as well as moral, political, and social knowledge.

One byproduct of the reconstruction of Japan's educational methods was the creation of a distinction between certain classes. This emergence of class divisions within the Japanese society was a reflection of the idea of class conflict between the bourgeois (upper-class) and the working class. For the upper class, it was not uncommon for their children to seek education at more prestigious, overseas facilities due to their connections and financial stability. Many well-to-do families were able to send their children abroad to foreign countries where they could study subjects in places where new technology and educational systems were already in place. ${ }^{14}$ Japanese

${ }^{12}$ Pittau, 177.

${ }^{13}$ A description of Confucianism can be found in Andrew Gordon's A Modern History of Japan From Tokugawa Times to the Present (Oxford, 2003): 4-6. Confucianism focused on fostering high ethical quality and great intellectuality among people. Morality and respect were ideas that were to be cultivated and studied to bring about a strong sense of spirit among the Japanese.

${ }^{14}$ Jordan Sand, House and Home in Modern Japan: Architecture, Domestic Space, and Bourgeois Culture, 1880-1930 (Cambridge; London: Harvard University Asia Center, 2003), 13, 15. 
architectural students, who had the means to travel, would go and train under well established architects in Europe and the United States, often bringing back the styles and knowledge they acquired to Japan, integrating Western forms of engineering and architecture into Japanese society.

The distinct emphasis on being well versed in European forms was evident in the manner that Japanese students constructed their ideas about the direction they thought Japanese architecture was heading towards in the future. When the Imperial College of Engineering began an architectural program in 1877 , many of the practical studios were the environment in which students learned and were expected to master Western forms. ${ }^{15} \mathrm{Ar}-$ chitectural education in European designs was seen as an important part of the architectural program; the reason behind the creation of this program was deemed as trying to "prepare Japanese to design buildings in Western architectural styles using modern building technology." ${ }^{16}$ The focus on Western education supported the notion that in order to move forward with the development of better designs, Japanese architects had to be open to foreign styles with their new materials and technology.

In addition to practical work, students at the Imperial University in Tokyo were required to write a thesis paper on different aspects of architecture and domestic spaces. Their papers were written in English reflecting the architectural education they received from English-speaking, and often Western educated, professors. Each written theses had an extensive history and description of historic European and Western forms of architecture, particularly Gothic, Grecian, and Roman architectural styles, structure, and materials. A good portion of each thesis addressed the influence of Western forms on architectural history and its potential to affect new Japanese styles or how it had presently changed traditional Japanese forms.

The idea that Western and European architectural style and engineering was more advanced and stable than that of Japanese architecture was a motivation to incorporate more Westernized qualities of design into Japan's buildings and homes. Japanese architectural students acknowledged that there were some major advantages to using materials and forms from Western forms. The stone, concrete, and brick buildings prevented fires from

\footnotetext{
${ }^{15}$ Reynolds, "Teaching Architectural History in Japan," 530.

${ }^{16}$ Reynolds, "Teaching Architectural History in Japan," 531.
} 
spreading to other buildings, unlike the wooden construction found with most domestic and public buildings. ${ }^{17}$ Attention to the detail of using more Western uses of materials focused in onto something small as roofing material, where tile was suggested for roofs to keep moisture from snow and rain from leaking through. ${ }^{18}$

In response to the climate of Japan, Western materials were substantial enough to withstand the harsher aspects of the external conditions of the country. More stable structures that were constructed with stone and concrete had stronger foundations that could help protect buildings from the earthquake forces that were known to occur in Japan. Also engineering factors such as loads from people occupying buildings and snow accumulating on roofs made architects lean more towards the seemingly sturdier Western forms of architecture with Roman arches which could withstand great compression from weight applied to the building. ${ }^{19}$

From studying foreign styles and materials of architecture, the Japanese students knew that in some ways, other forms of construction were equal, if not better, than the elements of their own native architecture. However, the reality was that although new technology emerged from the influence of the West, at times the Japanese style proved to be the more appropriate architectural context for Japan. From more traditional style of architecture for comfort or uses of traditional materials for safer buildings, the affinity towards more natural Japanese design was still apparent. The habits and customs of the Japanese set the ideal way of life that architecture and space needed to adjust to, creating a distinct style that would be hard to leave behind even in the age of Western ideas and technology.

Within the more personal setting of a domestic dwelling, the everyday habits and routines of the Japanese occupants gave purpose to the use of more traditional designs of spaces and homes. For the Japanese, the designs of the interior of their homes were more open and flowing compared to more structured layouts. Paper screens were used in between rooms to account for customs such as warming rooms with charcoal fire in a hibachi

${ }^{17}$ Satachi Shichijiro, "The Future Domestic Architecture of Japan" (Graduation thesis, Imperial College of Engineering, 1879), 8.

${ }^{18}$ Satachi, 8.

${ }^{19}$ Tatsuno Kingo, "The Future Domestic Architecture" (Graduation thesis, Imperial College of Engineering, 1879, 13-20. 
(firebox) that would produce smoke. ${ }^{20}$ Europeans viewed this custom as being odd, permitting smoke to reside within the home, but the breathable material used in the arrangement of the interior allowed the smoke to flow out of the house better than the solid walls usually found within Westernized interiors.

In regard to structural safety, Japanese use of more natural materials such as wood, which was abundant in their country, was deemed by Westerners as weaker in comparison to the apparent sturdiness of solid stone and concrete. In the 1891 earthquake centered in Nobi, Japan, doubt toward the superiority of Western uses of material within structures rose within the Japanese community. ${ }^{21}$ Many were surprised that many of the wooden buildings that were fairly older than the new European stone and masonry material-based buildings were able to weather the shocks of the earthquake better. Was it worth it to move towards engineering materials that did not perform as well during natural disasters as traditional Japanese architectural components? There were advantages to developing Western technology and styles within Japan's own architectural landscape, but would it be beneficial to concentrate their efforts on fostering this growth while edging out customary forms?

Bruno Taut, a German architect that visited Japan and studied its present architecture as well as its history during the late Meiji period, acknowledged that like many representative forms of culture of countries, over time they are subject to change. "Like waves of fashion, like the length of skirts, the courses change and will replace one another until fundamentals have been agreed upon and a continuous work begun." ${ }^{22}$ Every different style offered strength, beauty, and practicality, but the logical question in reference to where Japanese architecture was heading during the Meiji era would be: Would the Japanese have to settle for one style or the other? How would their course change?

\footnotetext{
${ }^{20}$ Sone, 25.

${ }^{21}$ Gregory Clancey, Earthquake Nation: The Cultural Politics of Japanese Seismicity, 1868 1930 (Berkeley and Los Angeles: University of California Press, 2006), 4.

${ }^{22}$ Bruno Taut, Fundamentals of Japanese Arcbitecture (Tokyo: Kokusai Bunka Shinkokai (The Society for International Cultural Relations), 1936), 9.
} 


\section{The "Both-And" Situation and National Identity}

"The architecture of a country can be only improved, not by entire translation but by substituting the superior principle in the other."

- Taki Daikichi, Imperial College of Engineering graduation thesis, $1883^{23}$

The "technological transfer" that was experienced by the Japanese produced the question of national and cultural identity. The confusion about which style would best represent the Japanese way of life made it difficult to settle on just one specific style. The dilemma of abandoning the traditional architectural styles for the new technological and Western advances created a similar consensus among the future architects of Japan: it would be beneficial to combining the best aspects of both worlds. The compromise between the two could create a better form of building design to benefit the Japanese and ease their struggle with choosing one or the other.

"The familiar intercourse of the Japanese with their ideas is the source of a great refinement to our country," Sone Tatsuzo stated, acknowledging that combining information with other cultures was beneficial to create a more polished society. ${ }^{24}$ This recognition of mutual influence among other nations, particularly China and Korea in the past, demonstrated the natural tendency for Japan to adopt different cultural aspects into their society to complement their native style. Taki Daikichi, another architecture student, wrote, "I'm more inclined to improve our buildings by borrowing superior principles in others rather than to sacrifice our own conveniences and ideas to fit the principles and requirements in others." ${ }^{25}$ Daikichi's insight into the exchange of cultural elements alluded to the idea that the Japanese should not be changed to fit the designs of other countries, but to use concepts from the others to better what was already present in their culture.

The hybridism of domestic homes with European exteriors and Japa-

${ }^{23}$ Taki Daikichi, "Future Architecture in Japan" (Graduation thesis, Imperial College of Engineering, 1883), 2.

${ }^{24}$ Sone, 5 .

${ }^{25}$ Taki, 25. 
nese interiors were able to give residents a way to use new materials and styles while holding on to the comforting, traditional aspects of the Japanese home. The private domain for a person was a reflection of what they considered most important in their lives, aspects of life they liked were kept in close proximity. For the Japanese, maintaining the essence of their culture and the familiarity of more traditional environments within their personal realm helped to keep their identity as they delved into foreign styles. For many, the presence of Japanese-style aspects in dwellings was essential to people's lifestyles.

"The men of high rank and the merchant of large fortune recently built their abodes in a pure European style, yet in ninety-nine cases out of a hundred there were formed the rooms of Japanese arrangement to sit down in the habitual manner, within the building, or instead of them, there were subordinately built Japanese houses, or else they cannot comfort themselves."

- Sone Tatsuzo, Imperial College of Engineering, $1879^{26}$

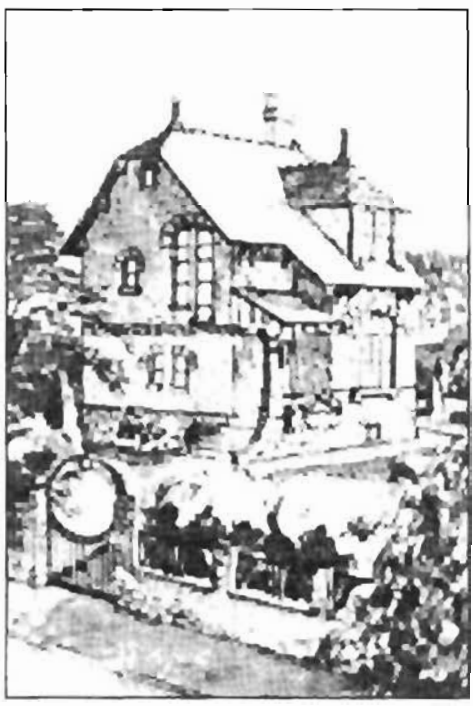

Figure 1. "Pure French" design created by Yasuoka Katsuya in the catalogue, Japanized Small Western Homes. Designs like these signaled a change in the styles of Japanese residential homes. From Jordan Sand's House and Home in Modern Japan, 269.

${ }^{26}$ Sone, 26. 
In the late Meiji period during the 1900s, this form of hybridism became a part of the "mass market" of people looking to create domestic spaces in accordance to changing times. Just as Western styles of clothing, furniture, and decoration became embodied in Japanese lifestyles, so was its architectural features. The use of the two different styles of materials and forms led to series of domestic homes that reflected the fusion. Japanized Small Western Homes was a catalogue that presented Japanese families with houses that were built in varying European styles, but still had some Japanese aspects to its design. ${ }^{27}$ These houses were described as "seven parts Western and three parts Japanese" as the catalogues advertised houses that were "Swiss chalet", "pure German", and other European styles. ${ }^{28}$ (See Figure 1.)

This commercialization of Westernized, but Japanese, homes showed the growing influence that foreign styles had on the cultural formation of the most personal and identifying spaces of a person, their own home. This implementation of foreign designs revealed the gravitation towards what was seen as exotic to the Japanese. Just as Westerners observed Japanese ways of life and cultural styles in art and architecture as different and intriguing in their unfamiliar ways, so did the Japanese have a similar fascination with the unknown of which they wanted to gain understanding. This concept is explored in the recent theory of Occidentalism, the opposite of Orientalism.

Orientalism, characterized by Edward Said in his work of the same name, was the creation of the idea of "the other," or the unknown culture, group, people that distinct in their own way. It is the study of different people and cultures by another group of people relative to what is they know of their own culture. This idea and study was created by Westerners in the observation of the Eastern world and their seemingly exotic and different lifestyles and traditions into which they wanted to gain insight. ${ }^{29}$ In this way, the understanding gained from studying the other culture would result in the formation of opinions on the value of each society in comparison to each other.

${ }^{27}$ Jordan Sand, House and Home in Modern Japan: Arcbitecture, Domestic Space, and Bourgeois Culture, 1880-1930 (Cambridge; London: Harvard University Asia Center, 2003), 268.

${ }^{28}$ Sand, 268.

${ }^{29}$ For more on Orientalism look to Edward W. Said's Orientalism (Vintage Books, 1979). 
The idea that the Japanese were fascinated by the differences in lifestyle, art, and architecture of other countries, particularly Western ones, retains the same ideas of Orientalism, but turns it around and sees it from the point of view of "the Orient". With this notion of Occidentalism, the Orient is able to study how the "Western Other" view their lifestyles and customs. Through the analysis of the comprehension of Eastern culture by the Western Other, the Orient is able to "participate actively and with the indigenous creativity in the process of self-appropriation." ${ }^{30}$ By looking at the Western accounts of what their culture was about and their opinions of the Orient's culture, the Orient would be able to reinterpret their "nonWestern realities mainly through the looking glass of Western theory." 31 The Orient is able to compare their own concept about who they are to the insights formed by the Westerners and their Western culture to determine how to move forward with their own society. For the Japanese, architecture was a point in their culture where observing Westerners provided a catalyst for change.

The change to Western and modern materials spawned discourses on what represented the Japanese as a distinct people, what would provide a strong sense of identity among other countries. The concept of national identity seen in the context of Japanese architectural history can be explained through Benedict Anderson's theory of nationalism and imagined communities. ${ }^{32}$ Even though each individual person in Japan may not have identified with each other because they had never met personally, they still had a sense of unity and national identity through a common idea that the nation itself created, whether it was a tangible object such as a building or a concept like architectural styles.

One of the most important discourses, that proved the ongoing struggle between established and foreign ideas of what architecture should be in conjunction with national identity, would concern one of the most promi-

\footnotetext{
${ }^{30}$ Xiaomei Chen, Occidentalism: A Theory of Counter-Discourse in Post-Mao China (New York, Oxford: Oxford University Press, 1995), 5.

${ }^{31}$ Chen, 17.

${ }^{32}$ See Benedict Anderson's "The Origins of National Consciousness" from Imagined Communities: Reflections on the Origin and Spread of Nationalism (London, NY: Verso, 1983; rpt., 2006), 1-7, 37-46.
} 
nent institutions in Japan, The Imperial Diet. ${ }^{33}$ For the Japanese, The Imperial Diet was a reflection of the Western government used in the Meiji government. Because the governmental division itself was supposed to be representative of Japanese government, the Diet building was supposed to "represent a vision of Japanese identity both domestically and internationally," and act as a unifying symbol. ${ }^{34}$

Much of the debate that surrounded the creation of a new Imperial Diet building was made among politicians and architects who wanted to pinpoint a design that would encompass the spirit of Japan. Many of the designs presented were made by foreign architects; the government wanted the building to be rooted in modernity as Japan moved towards a new age. What came out of these foreign architects were designs that either embraced Japanese aspects of architecture or moved away from them. One German architecture firm came up with two different designs: one with a straight European style and no Japanese details and one that alluded to Japan's architectural past through small details. ${ }^{35}$ Part of the use of Japanese style was aimed at composing an "exotic hybrid" (orientalized design) as seen by Westerners; though the main design style was foreign, Japanese details were used to create portions of a design that would reflect the country and its people. ${ }^{36}$ (See Figures 2.1, 2.2.)

Following the lines of combining styles, the emergence of the combination of European classicism with "pure" Japanese elements was brought into Japanese consciousness through the teikan style, the imperial crown synthesis style. ${ }^{37}$ Shimoda Kikuataro, a Japanese architect who entered the contest for the Imperial Diet design in 1918, presented his work in

${ }^{3}$ A description of the branch of the Japanese government, The Diet, can be found in Andrew Gordon's A Modern History of Japan From Tokugawa Times to the Present (Oxford, 2003): 77-93. The Diet marks its beginning in 1890 as the parliament of Japan. It was created through the Meiji Constitution to address the political debates and practices that had formed during the Meiji era. The Diet represented then, as it does now, a large part of the political life of Japan.

${ }^{34}$ Jonathan M. Reynolds, "Japan's Imperial Diet Building: Debate over Construction of a National Identity," Art Journal, 55, no. 3 (Fall 1996): 38.

${ }^{35}$ Reynolds, 40.

${ }^{36}$ Reynolds, 40.

${ }^{37}$ Isosaki, 3. 


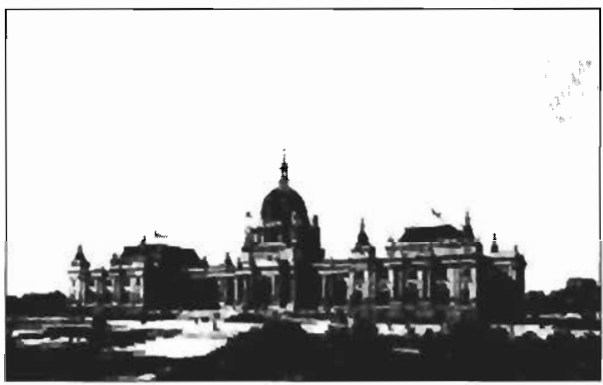

Figure 2.1. European-style design created by Wilhelm Bockmann. Western characteristics such as the dome, columns, columns, and bilateral symmetry. 1887 entry version 1. From Jonathan Reynolds' "Japan's Imperial Diet Building," 40.

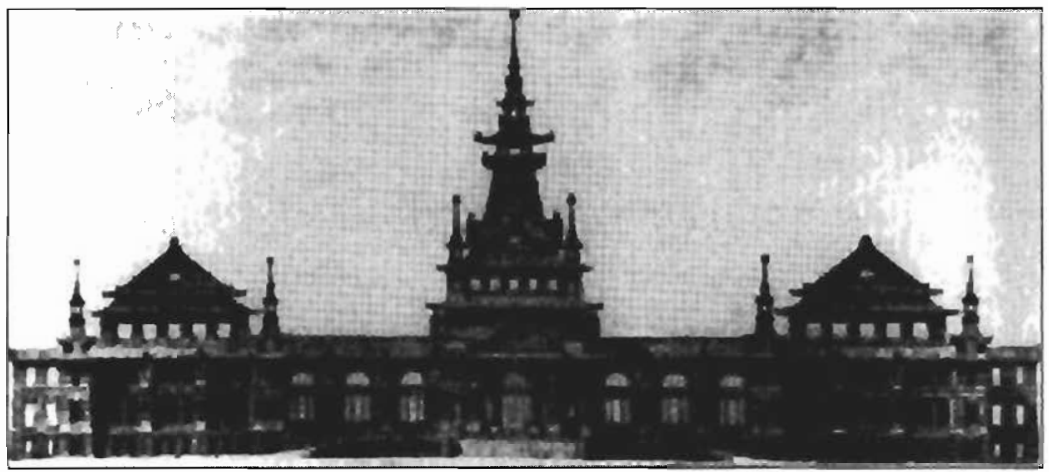

Figure 2.1. European-style design created by Wilhelm Bockmann. Western characteristics such as the dome, columns, columns, and bilateral symmetry. 1887 entry version 1 . From Jonathan Reynolds' “Japan's Imperial Diet Building,” 40.

this particular combination of Japanese and Western concepts. ${ }^{38}$ His work tried to represent the possible future of architecture during the Meiji era; he tried to suitably represent the best of both architectural styles in one building, making the building both aesthetically pleasing and respectful of Westernized forms and of Japan's desire for national identity. Despite the creative effort at reconciling the two different styles, his juxtaposition of European and Japanese styles was attacked by his colleagues; instead of seeing a strong illustration of both forms, his colleagues believed that the

\footnotetext{
${ }^{38}$ Reynolds, 43.
} 
designs undermined the basic nature of each style and chose to reject the proposals. ${ }^{39}$

Eventually a neoclassical design was chosen for the Diet building which contained Japanese decorative motifs. The use of a primarily European design never really reached the "status of a national symbol that resonated with the Japanese public." ${ }^{+0}$ The form did not reflect, adequately, the Japanese style that would have given the building more accurate projection of Japan and its people. The Diet building was a chance for Japan to use modern materials and designs to become this physical representation of their national pride and identity, but the final Western-style edifice was unable to evoke that image among the Japanese. (See Figure 3.)

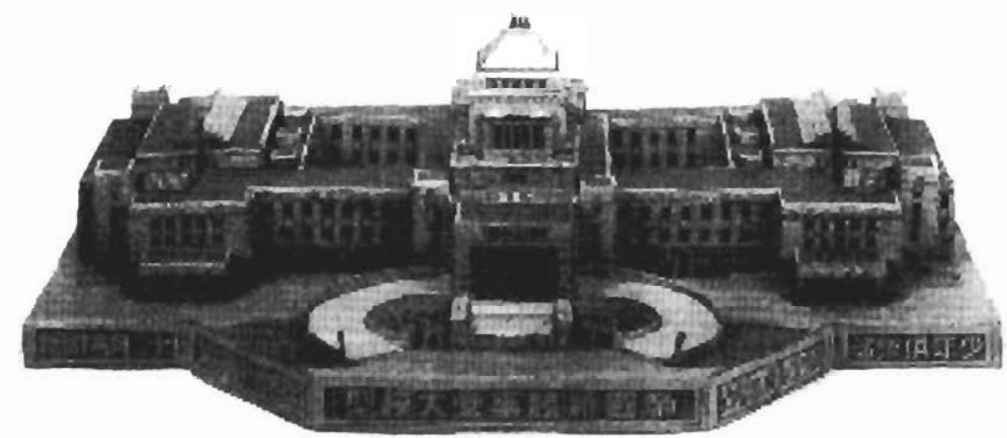

Figure 3. After the first Imperial Diet building burned down in January 1891, this final design for the Imperial Diet building was composed as a permanent replacement in lieu of a temporary building that was constructed. The final edifice was built out of steel, reinforced concrete, and gray granite. This design has Japanese details which only accounts for a small portion of the overall neoclassical construction with its towers, stepped roofs, and columns. It is a compromise of styles to bring a modern building to life. This picture of a model of the final building is from Jonathan Reynolds' "Japan's Imperial Diet Building," 46.

For the Japanese, the creation of combined styles within their architectural world gave them conflict over national identity as they tried to find the right balance between modern designs with traditional aspects of

\footnotetext{
${ }^{39}$ Reynolds, 44.

${ }^{40}$ Reynolds, 47.
} 
Japanese architecture. The evolution of the architectural landscape of Japan emerged through their sense of national pride interpreted through changing technology and new education.

\section{Conclusion}

The transference of knowledge of technology and architectural styles set the future of Japan on a course to adjust both their physical, outward appearance while at the same time changing the core of their ideas of national identity and culture. The transformation of Japanese life in relation to the introduction of Western educational opportunities of learning modern materials, technology, and structures has been seen as reaching into all aspects of Japan as a country during the Meiji period.

As a strong nation in Asia among others being taken over and colonized by Westerners, Japan looked to staying an independent and influential country to avoid the same fate. In order to keep their status as a greatly educated and united nation, adaptations to the new world order from 1868 onward had to be made to promote further progress in the international arena. The Japanese not only had to be well-informed politically about where it stood among the ranks of powerful European and other Western countries, but they had to support their own position through strengthening their cultural and social elements of their nation.

From the goals to become a greater people came improvements to assist their efforts to keep up with the modern times. The educational system that was created gave opportunities for students to become more educated in new technology which was important for them to contribute more in research and development of Japanese engineering, art, and architecture. The improvement of the education of Japanese students led to the betterment of the country by creating more informed citizens to build up their nation through their use of their knowledge.

Through the changes made in the educational system, and the opportunities available to students to study abroad, the incorporation of Western ideas helped forge new identities as Japanese as well as helping to create new styles in architecture. The question of whether the use of Western styles, Japanese styles, or a mixture of the two could appropriately represent the Japanese culture and nation was the main issue that emerged during the Meiji period; the influence of modern technology and foreign forms of 
art and architecture became a point of discussion in regards to the development of the country's culture and style.

Ultimately, the conclusion that many Japanese and Western architects alike devised was a combination of Western and Japanese elements of design moved towards constructing a "hybrid" design that tried to encompass the new aspects of Western ideas while keeping the essence of Japanese design. The national identity of the Japanese people was important to keep intact not only through political and social movements, but also through the cultural changes, like architecture, that were made in response to changing environments, education, and interaction with other countries.

From the effects of bringing in foreign ideas and new technology, the architecture of Japan was forever changed by the infusion of forms and materials into its already present designs. The movement towards more focused education on expanding industries and the search for a representative style of Japan through new areas of developed ideas gave Japan a chance to move into the Meiji Era with a new outlook on its future; a future that involved adapting to the changing modern and technological times as well as keeping their traditions to create a better nation. 


\section{BIBLIOGRAPHY}

Bognar, Botond. Contemporary Japanese Architecture. New York: Van Nostrand Reinhold Company, Inc., 1985.

Chen, Xiaomei. Occidentalism: A Theory of Counter-Discourse in Post-Mao China. New York, Oxford: Oxford University Press, 1995.

Clancey, Gregory. Earthquake Nation: The Cultural Politics of Japanese Seismicity, 1868-1930. Berkley and Los Angeles: University of California Press, 2006.

Funakoshi Kinya. "The Adoption of European Architecture in Japan." Graduation thesis, Imperial College of Engineering, 1883.

Isozaki, Arata. Edited by David B. Stewart and translated by Sabu Kohso. Japanness in Architecture. Massachusetts: The MIT Press, 2006.

Pittau, Joseph "Inoue Kowashi (1843-1895) and the Meiji educational system," in Modern Japan: An Interpretive Anthology, ed. Irwin Schiener, 176-189. New York: Macmillan Publishing Co., Inc., 1974.

Reynolds, Jonathan M. "Japan's Imperial Diet Building: Debate over Construction of a National Identity." Art Journal, 55, no. 3 (Fall 1996): 38-47.

Reynolds, Jonathan M. "Teaching Architectural History in Japan: Building a Context for Contemporary Practice." The Journal of the Society of Architectural Historians, 61, no. 4 (Dec., 2002): 530-536.

Sand, Jordan. House and Home in Modern Japan: Architecture, Domestic Space, and Bourgeois Culture, 1880-1930. Cambridge; London: Harvard University Asia Center, 2003.

Satachi Shichijiro. "The Future Domestic Architecture of Japan." Graduation thesis, Imperial College of Engineering, 1879.

Sato, Seizaburo. "Japan's World Order." In Modern Japan: An Interpretive Anthology, ed. Irwin Scheiner. 9-17. New York: Macmillan Publishing Co., Inc., 1974.

Smith, Thomas C. "Old Values and New Techniques in the Modernization of Japan." In Modern Japan: An Interpretive Anthology, ed. Irwin Scheiner. 95-103. New York: Macmillan Publishing Co., Inc., 1974. 
Sone Tatsuzo. "The Future Domestic Architecture." Graduation thesis, Imperial College of Engineering, 1879.

Taki Daikichi. "Future Architecture in Japan." Graduation thesis, Imperial College of Engineering, 1883.

Teikichi Ono. "An Essay on Architecture." Graduation thesis, Imperial College of Engineering, 1891.

Tatsuno Kingo. "The Future Domestic Architecture." Graduation thesis, Imperial College of Engineering, 1879.

Taut, Bruno. Fundamentals of Japanese Architecture. Tokyo: Kokusai Bunka Shinkokai The Society for International Cultural Relations, 1936. 